\title{
Financial Inclusion: Role of Pradhan Mantri Jan Dhan Yojna and Progress in India
}

\author{
Pramahender $^{1}$, Narender Singh ${ }^{2}$ \\ ${ }^{I}$ (Research Scholar, Department of Commerce, Kurukshetra University, Kurukshetra) \\ ${ }_{2}^{2}$ (Chairperson, Department of Commerce, Kurukshetra University Kurukshetra)
}

\begin{abstract}
Financial inclusion means providing financial products and services to people at very low cost or providing financial services to that section of society, which do not have basic banking facilities, such as saving accounts or deposit and payment facility. ${ }^{.}$For effective growth of economy, it is necessary to involve those people in banking sector who are not having access to banking sector, so that they can avail benefits of banking services and facilities, and develop habits of small savings. This paper describes that what is the status and progress report of Pradhan Mantri Jan Dhan Yojna and what are various challenges in the way of financial inclusion in India. This paper is descriptive in nature and simple trend analysis is used to describe progress of (PMJDY), paper also described various challenges faced by financial inclusion in India as well various steps taken by authorities to promote financial inclusion in India. Study suggest that private and public sector banks along with Government and RBI has to play much active role in creation of awareness among deprived section of society, and to design more innovative products for the poor section to promote financial inclusion in India.
\end{abstract}

Keyword: banking, inclusion, innovative moneylenders, productive.

\section{INTRODUCTION}

Financial inclusion means providing financial services such as basic bank accounts and deposit and saving facility at very low cost to poor section of society or to those who are not having access to banking sector so that they can also enjoy basic banking facilities and they can be integrated with formal banking system. Concept of financial inclusion came in to existence in 2005 in India when its importance was recognized and relaxation given to banking sector to come with best strategies to involve people in banking sector by providing banking facilities at very low cost. Reserve bank of India is playing its central role in promotion of financial inclusion so that involvement of every single household can be achieved. Although Government of India and our banking sector are making efforts to achieve targets of financial inclusion and getting favourable results in this side also. There are some challenges also in way of financial inclusion, which are acting as barriers to achieve targets of financial inclusion. Financial inclusion or access to banking sector is touching lives of needed and poor people, they are getting a wide range of financial services at very low cost and they are managing their resources in productive way because in absence of formal system, moneylenders would exploit them. Most of the population of India is living in rural areas that $\mathrm{s}$ why they have less access to formal banking sector here role of financial inclusion becomes active by providing banking facilities to rural population and involving them in circle of finance.

\section{ObJeCtives ANd ReSEARCH Methodology}

OBJeCtives Of The STUdY:

Followings objectives have been framed for the purpose of the study

a. To make a review of progress of PMJDY and financial inclusion process

b. To find out the challenges in way of Financial Inclusion.

c. To find out the ways to achieve objectives of financial inclusion in India

Data sources: Present study is descriptive in nature based on secondary data, which is obtained from various sources such as Govt. Publications, Annual report of RBI, report of CRISIL on financial inclusion and various published sources about financial inclusion to make this study understandable and simple.

\section{REVIEW OF LITERATURE}

Hema and Divya found that financial inclusion is very useful tool for low income and no advantage group of study. Found that financial inclusion has shown good level of performance during last three decades, 
there is need to improve financial services and delivery of banking products delivery mechanism to provide strength to financial inclusion and banking or financial institutions need to put some efforts on their own basis to improve financial inclusion basis in the country. ${ }^{2}$ Sharma, Kukerja described that in India only 35 percent people had bank accounts while it is 50 percent at global level and this ratio is 41 percent in developing countries and financial inclusion is essential for economic growth yet financial inclusion has not achieved needed results yet there is road ahead to go on in this direction. ${ }^{3}$ Sharma and Pais found that level of human development and financial inclusion move together; better human development will lead to better level of financial inclusion. ${ }^{4}$ Shabna Mol TP described that out of total 19.9 crores households only 6.82 crores households have access to banking industry and in case of rural areas out of 13.83 crores households only 4.16 crore households have bank accounts which shows very low level of access to banking facilities ${ }^{5}$ Aggarwal and Garg Defined that although regulator and government, banks and others make efforts yet results are not according to the need or expectation. Banks need to leverage information communication and technology along with innovative products for poor and needed section ${ }^{6}$

\section{Progress Of Pradhan Mantri Jan Dhan YoJna In Financial InClusion}

The National Mission on Financial Inclusion or Pradhan Mantri Jan Dhan Yojna was started by Ministry of Finance, Department of Financial Services, Government of India, with a wide vision to provide access to banking facilities to those people who are not having any bank accounts or still unbanked from formal banking sector, so that they can also be involved in banking sector which is necessary for economic development and for the welfare of poor people. Under this scheme people will get basic bank accounts with insurance facility and an additional facility of overdraft. Thus they will avail benefit offered by banks and facilities provided by government and will be able to develop small savings habits among them, and it will enhance capital formation, which will in result increase economic development of country.

Table I. defines progress report of Pradhan Mantri Jan Dhan Yojna

TABLE I. Progress Report of PMJDY as on 24 Feb 2016

\begin{tabular}{|l|l|l|l|l|l|l|}
\hline Banks & $\begin{array}{l}\text { Rural } \\
\text { Accounts } \\
\text { (crores) }\end{array}$ & $\begin{array}{l}\text { Urban } \\
\text { Accounts } \\
\text { (crores) }\end{array}$ & $\begin{array}{l}\text { Total } \\
\text { Accounts } \\
\text { (crores) }\end{array}$ & $\begin{array}{l}\text { No. of } \\
\text { Debit } \\
\text { Cards } \\
\text { (crores) }\end{array}$ & $\begin{array}{l}\text { Balance (Rs } \\
\text { crore) }\end{array}$ & $\begin{array}{l}\text { \%age of } \\
\text { Account } \\
\text { with zero } \\
\text { Balance }\end{array}$ \\
\hline PSB & 9.22 & 7.30 & 16.53 & 14.08 & 26094.05 & 29.41 \\
\hline RRB & 3.19 & 0.53 & 3.72 & 2.67 & 5756.44 & 24.50 \\
\hline PRIVATE & 0.45 & 0.30 & 0.75 & 0.71 & 1224.40 & 38.87 \\
\hline TOTAL & 12.87 & 8.13 & 21.00 & 17.46 & 33074.89 & 28.88 \\
\hline
\end{tabular}

Source: Ministry of Finance, Govt of India, www.mof.gov.in

Since from its inauguration on august 28, 2014 the PMJDY scheme of financial inclusion is becoming very effective. Above table indicates that public sector banks are playing their role in making the scheme a success with approx. 9.22 crore accounts in rural areas and 7.30 crore accounts in urban areas and involving more and more people with formal banking system. As purpose of financial inclusion is to provide low cost banking services and facilities to poor section and to those who are financially excluded that $\mathrm{s}$ why most of the accounts are opened with zero balance bank account table reveals that out of 21.00 crore accounts opened so far 28.88 percent accounts have been opened with zero balance accounts.

Debit card facility is also looking very helpful to poor people where they can withdraw money at any time and at any place according to the table 17.46 Crores debit cards have been issued so far by all banks including public, private, and rural regional banks which shows that banks are achieving their targets of financial inclusion. 
IOSR Journal of Business and Management (IOSR-JBM)

e-ISSN: 2278-487X, p-ISSN: 2319-7668

Table II. contains details of household coverage of various states under financial inclusion

TABLE II. State wise Household Coverage as on 24 Feb. 2016

\begin{tabular}{|l|l|l|l|l|}
\hline Serial Numbers & States & Total Household & $\begin{array}{l}\text { Covered } \\
\text { Household }\end{array}$ & $\begin{array}{l}\text { Percentage } \\
\%\end{array}$ \\
\hline 1 & $\begin{array}{l}\text { ANDAMAN } \\
\text { NICOBAR }\end{array}$ & 67287 & 67287 & 100 \\
\hline 2 & ARUNANCHAL & 197861 & 197861 & 100 \\
\hline 3 & ASSAM & 5013404 & 5011228 & 99 \\
\hline 4 & BIHAR & 17281831 & 17281831 & 100 \\
\hline 5 & MANIPUR & 514604 & 513359 & 99 \\
\hline 6 & MEGHALAYA & 477182 & 477182 & 100 \\
\hline 7 & MIGORAM & 181946 & 181806 & 99 \\
\hline 8 & NAGALAND & 334034 & 333762 & 99.99 \\
\hline 9 & SIKKIM & 131086 & 131086 & 100 \\
\hline 10 & CHANDIGARH & 193876 & 193876 & 100 \\
\hline
\end{tabular}

Source (Ministry of Finance, www.mof.gov.in)

Above table is showing details about no. Of households in each state and households covered under the scheme PMJDY. Here data have been taken from those states which are not having enough banking facility especially Northeast states and states such as Bihar. Above table is describing that most of states have achieved targets of financial inclusion by covering maximum households and this scheme of financial inclusion will be very helpful in north east states by ensuring mass participation of people and their integration with formal banking sector.

\subsection{RESERVE BANK OF INDIA REPORTS}

- According to report of NSSO 59 round of survey results shows that in India 51.4 percent of farmer household do not have access to formal and informal sector of banks

- Out of total household of farmers only 27 percent household have access to formal credit

- Out of total farmers households of India 73 percent have informal access of credit which shows huge gap of access to banking facility

Graph one present the details of access to formal and informal sources of finance.

GRAPH 1:

Chart 1: Access to Formal and Informal Sources

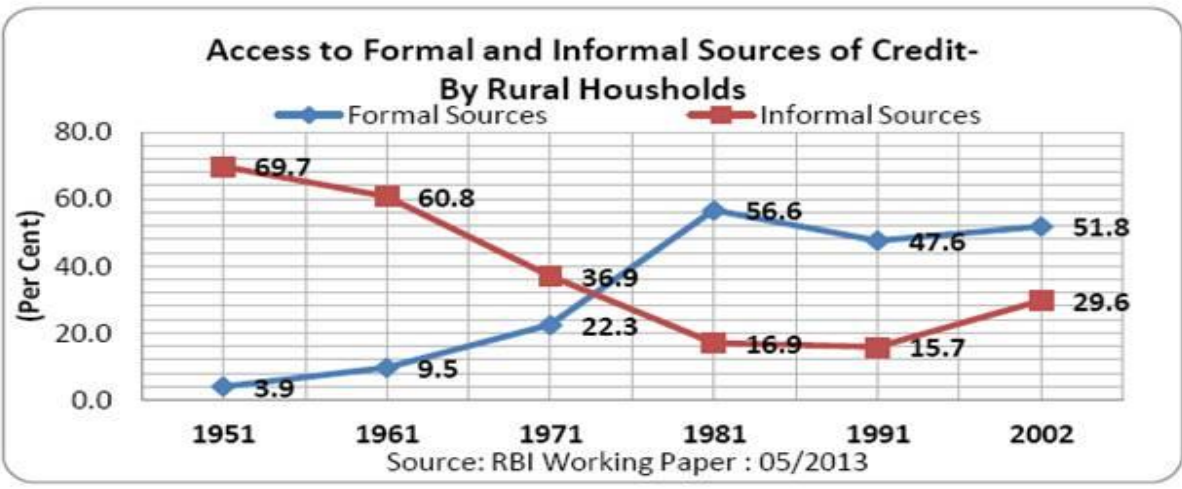

Source www.rbi.org.in

Above graph is showing that access to informal sector of credit in 1951 was 69.7 percent which is declining on continue basis and at its lowest level at 29.6 in 2002 means people are getting more involvement with formal sector. On the other hand look at formal sector of credit such as banks, financial institutions and 
other formal sources are increasing every time and they are attracting people in formal banking sector, in 1951 access was 3.9 percent which move to 52 percent in 2002 and moving further upward.

Graph 2 contains the details about access to banking services to rural and urban population

GRAPH 2:

Access to Banking Services

\section{Chart 2: Availing of Banking Services}

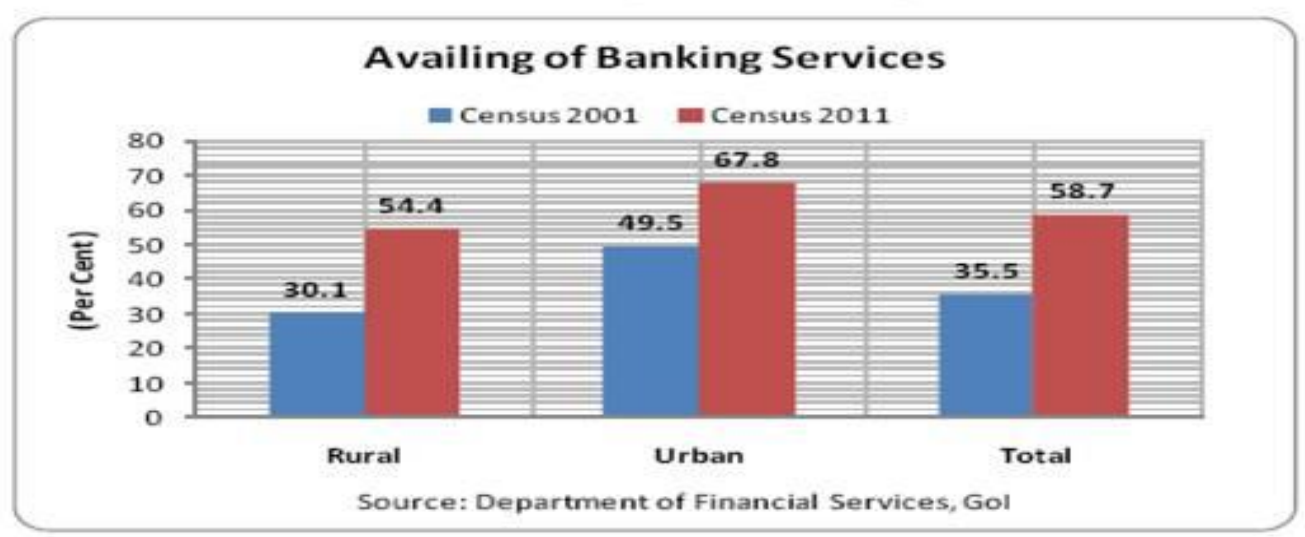

Source www.mof.goi.in

According to census report of 2011 results are as that out of total population only 58.7 percent population have access to banking services and remaining 42 percent do not have access to banking services, which shows that there is long road ahead to travel for financial inclusion.

\subsection{INDEX OF FINANCIAL INCLUSION: CRISIL INDIA REPORT}

Index of financial inclusion prepared by credit rating agency CRISIL that measures the inclusiveness of financial services and products among population, this index is based on three dimensions, which are as

a. Financial Accessibility

b. Financial Availability

c. Usage of Financial Services

These dimensions used to measure depth and access of financial services and financial products to people of that particular area. Value of index of financial inclusion is between zero to1, where zero stands for no access to financial services or very low level of financial inclusion. Value between 0 to 0.30 stands for medium value means average access to financial services and where value is one that shows high level of financial inclusion, list of states with their financial inclusion position is given which describes level of states with their access to banking facility.

A. Low Level of Financial Inclusion Value (Below .30)

West Bengal, Gujarat, Utter Pradesh, Tripura, Odisha, Rajasthan, Mizoram, Bihar, Assam, Nagaland, Manipur, and Meghalaya

B. Medium Level of Financial Inclusion Value (Above .30)

These states are having moderates services and access to banking sector and with the help of little efforts these states converted into high level of financial inclusion states and these are

Tamil Nadu, Punjab, Andhra Pradesh, Himachal Pradesh, and Haryana

C. High Level of Financial Inclusion Value of Index is (1)

These are states, which are having very good position in financial inclusion, and people of these states are having access to banking products and services and these states are

Kerala

Maharashtra

Karnataka 


\section{GRAPH 3:}

\section{Progresses Report of Inclusix an Index for Financial Inclusion Chart 3: CRISIL - Inclusix}

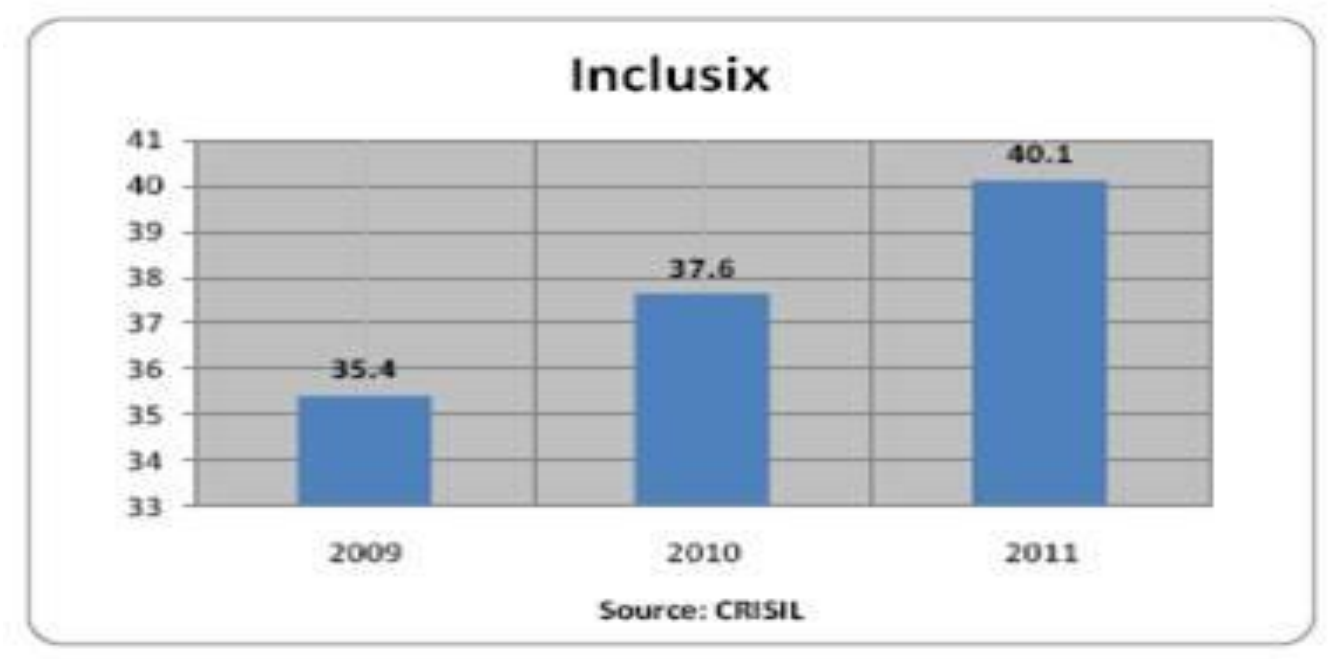

Source www.crisilindia.in

Above index is showing that overall position of financial inclusion in India is increasing in 2009 when inclusix was 35.4 percent, which went up to 37.6 percent in 2010, and 40.1 percent in 2011 showing a positive trend

\subsection{PROMOTIONAL STEPS TAKEN TOWARd FinANCIAL INCLUSION}

\section{a. No Frills Account}

Reserve bank of India has given directions to all commercial banks and regional rural banks to come forward and involve people in formal banking streamline. Banks are now opening bank accounts with zero balance and providing facilities to poor and unbanked section of society so that they can also get maximum benefits from banking sector.

\section{b. General Credit Cards}

With a view to provide credit facility to needed and poor section banks on the guidelines of RBI, are now issuing GCC to their customers. These general credit cards will help people to use finance for their production purpose and in turn, it will boost manufacturing and employment activities in rural areas. in upcoming time more and more GCC will be issued with other banking products, which will be helpful in circulation of finance among poor section of the society and improved picture of financial inclusion will emerge.

\section{c. Easy KYC Norms}

For making documentation, procedure simple and easy norms related to know your customers made simple so that more and more involvement of people secured. Now under scheme PMJDY you can open your bank accounts with a single document, this will encourage uneducated customers who are hesitating to go to banks just because of lengthy documentation process.

\section{d. Expansion of Rural Branches}

According to the guidelines of RBI now, every bank has to reserve 25 percent of their total branch plan for rural areas so that more and more rural branches can be opened and people, living in rural and remote areas can enjoy facilities offered by banks. Apart from this norms related with licensing for new branches are also relaxed so that banks can open more and more branches and expand their branch network. 
TABLE III. Details about Bank Branches and Numbers of Bank Correspondents

\begin{tabular}{|c|c|c|}
\hline YEAR & Banking Branches & Banking Correspondents \\
\hline March 2010 & 33378 & 34174 \\
\hline March 2011 & 34811 & 80802 \\
\hline March 2012 & 37471 & 141136 \\
\hline March 2013 & 40837 & 221341 \\
\hline
\end{tabular}

(Aggarwal and Garg)

\section{e. Leveraged ICT and Doorstep Banking}

i. With the advent in information and communication and technology banks are expanding their operations fastly, special strategies designed to suit the needs of needed customers making payments and withdrawal facility much easier.

ii. Banking correspondents employed in rural areas or in those areas, where there are no branches of banks these bank agents are working as helping hand to uneducated people to provide banking access, which is becoming popular nowadays.

\section{f. Financial Literature Programme}

To overcome the problem of financial illiteracy government of India and RBI has started to work on promotion of financial education to young customers and students to create awareness among them so that they can reap the benefits of banking system and use their knowledge for welfare of uneducated people

\section{CONCLUSION}

Involvement of people in financial system and formal banking sector is necessary for the development of country. Although, efforts have been made in this direction to achieve objectives of financial inclusion, yet there are challenges in way of success. The PMJDY is playing its role in great manner by ensuring mass participation of people and providing them low cost financial services and banking facilities, still there is need to impart financial knowledge and awareness among people about benefits of banks and basic banking facilities. Banks have to open more branches that are in rural areas and banking outlets in remote areas along with ATM. Innovative and well designed products, which can cater the needs of poor and needed people, PMJDY have to make efforts to achieve its targets by opening new accounts and ensuring less and less financial exclusion on continue basis.

\section{REFERENCES}

[1] A. Mukherjee, and S. Chakraborty, "Financial Inclusion of the poor and Marginalised in Jharkhand: Analysis of the Existing Model", International Journal on Research and Development-A Management Review (IJRDMR), 1(1), 2012.

[2] K. H. Divya, "A Study On Impact Of Financial Inclusion With Reference To Daily Wage Earners", Journal Of Business Management \& Social Sciences Research, 2(6), 2013, 85-92.

[3] A. Sharma and S. Kukreja, "An analytical study: Relevance of Financial Inclusion for developing nations", International Journal of Engineering and Science, 2013, 15-20.

[4] M. Sarma and J. Pais, "Financial inclusion and development", Journal of international development, 23(5), 2011, 613-628.

[5] T. P. Shabna Mol, "Financial Inclusion: Concepts and Overview in Indian Context", Abhinav International Monthly Refereed Journal of Research in Management \& Technology, 3(6), 2014.

[6] S. Garg, and P. Agarwal, "Financial Inclusion in India-a Review of Initiatives and Achievements", Journal of Business and Management (IOSR-JBM), 16, 2014.

[7] http://www.mof.gov.in

[8] http://www.crisil.info.in

[9] http://www.worldbank.in

[10] http://www.rbi.org 